\title{
Karl Friedrich Almstedt - scientist, teacher, and co-founder of the German Geophysical Society
}

\author{
Karl-Heinz Glassmeier ${ }^{1,2}$ \\ ${ }^{1}$ Institut für Geophysik und extraterrestrische Physik, Technische Universität Braunschweig, \\ 38106 Braunschweig, Germany \\ ${ }^{2}$ Max-Planck-Institut für Sonnensystemforschung, 37077 Göttingen, Germany \\ Correspondence: Karl-Heinz Glassmeier (kh.glassmeier@tu-bs.de)
}

Received: 3 January 2020 - Accepted: 9 March 2020 - Published: 16 April 2020

\begin{abstract}
The German Geophysical Society was founded in 1922 as the Deutsche Seismologische Vereinigung. One of the 24 founders of this society was Karl Friedrich Almstedt. Born in 1891 and deceased in 1964, Almstedt represents a generation of academics and scientists who grew up during the decline of the European empires, experiencing the devastations of the two World Wars and the cruelties of the Nazi era as well as the resurrection of academic and cultural life in post-war Germany. A detailed biographical sketch of Karl Almstedt's life is presented through historical notes on his social, political, and scientific environment.
\end{abstract}

\section{Early life and academic career}

Karl Friedrich Almstedt (Fig. 1a-b) was born on 22 October 1891 in Jerxheim near Helmstedt in the Duchy of Braunschweig. He was the son of Karl Almstedt and his wife Maria. Karl Almstedt, the father, was later the railway station master of the city of Braunschweig (Almstedt, 1913, p. 33). The construction of a railway network, started in 1838 in the Braunschweig region, was an important improvement of trade routes and led to very intensive industrialization in the Duchy of Braunschweig. Companies like Siemens AG or the Büssing van factory, pianos from Grotrian-Steinweg, sugar refineries, and the Schmalbach cannery made Braunschweig a prosperous city around the turn of the 19th to 20th centuries in the Prussian-dominated German Empire. It is this environment in which Karl Almstedt grew up.

He became a pupil of the Duchy's secondary school in Braunschweig, starting on 19 September 1903 (NLA WO, 2018) and graduating on 11 April 1909. Subsequently he started his academic education at the universities of Braunschweig, Munich, and Göttingen. His subjects were mathematics, physics, and chemistry. From autumn 1909 until spring 1911 he studied at the Technische Hochschule Braunschweig, moving to Munich for the winter term of 1910/1911 and the summer term of 1911 (LudwigMaximilians-Universität München, 1910, p.47; p. 48, 1911), finally finishing his studies at the University of Göttingen. At the Ludwig-Maximilians-Universität in Munich he attended lectures by e.g. Wilhelm Conrad Röntgen (1845-1923) and also met Ernst von Angerer (1881-1951), who was an assistant professor to Röntgen at that time (Ludwig-MaximiliansUniversität München, p. 30, 1910). Later, von Angerer was also involved in sound measurements and location of sound sources (von Angerer und Ladenburg, 1921).

Almstedt graduated to become Dr. phil. from the University of Göttingen. He defended his dissertation on Die Kälterückfälle im Mai und Juni (cold relapses in May and June) on 12 November 1913 (Fig. 2). His mentor was Emil Wiechert. Almstedt concluded the following (Almstedt, 1913, p. 32).

Kälteperioden in Norddeutschland werden in den Wintermonaten durch östliche und nordöstliche Luftströmungen verursacht, wobei jedoch auch die nächtliche Ausstrahlung eine große Rolle spielt. Die Kälterückfälle im April, Mai und Juni sind eine Folge nördlicher und nordwestlicher Luftströmungen, die immer bei einer gewissen charakteristischen Druckverteilung auftreten und ihre Ursache letzten Endes in der verschiedenartigen Erwärmung der Land- und Wasserflächen haben... Der Junikälterückfall ist keine so kurzwährende 
(a)

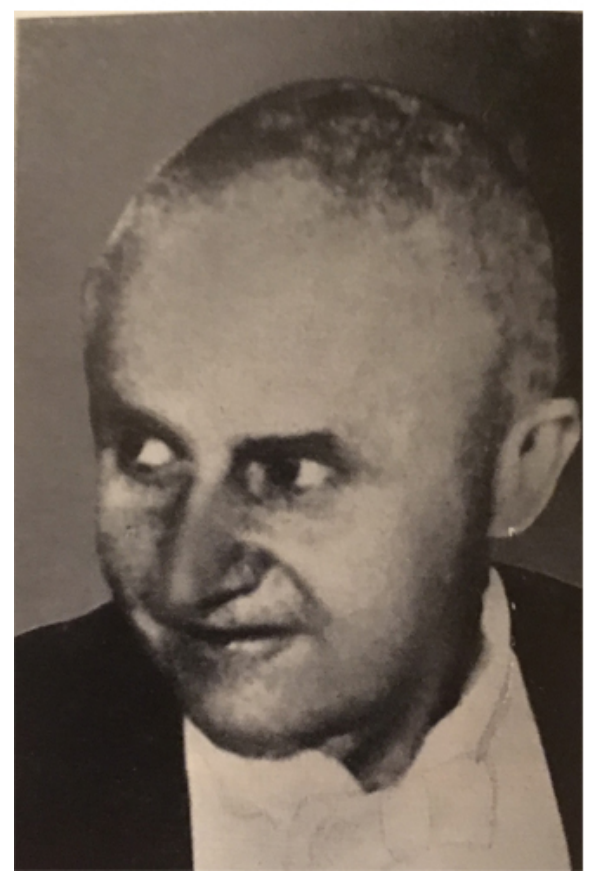

(b)

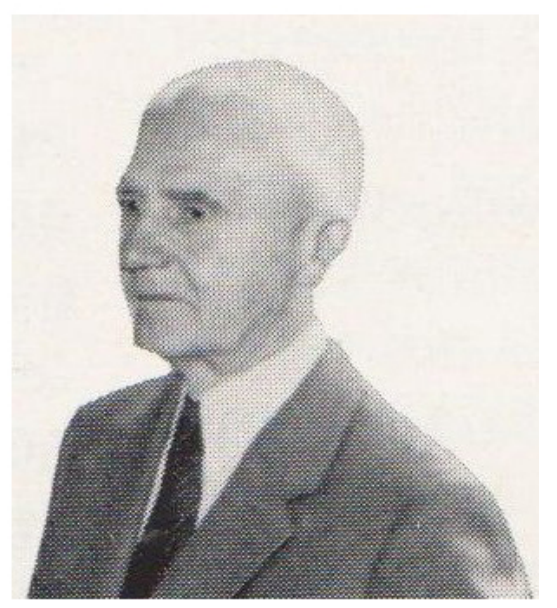

Figure 1. (a) Karl Friedrich Almstedt, around 1957 (from Bödecker, 1965, p. 78). (b) Karl Friedrich Almstedt, around 1964. This photo is reproduced from a brochure published on the occasion of the official opening of the new school building of the Ricarda-Huch-Schule in Braunschweig 1964; with the permission of Friedrike Borß.

Erscheinung, wie man bisher annahm, sondern stellt nur den Beginn eines größeren Naturphänomens dar, das sich über die Monate Juni, Juli und August erstreckt, und das man wegen seiner Ursachen und Begleiterscheinungen als einen Sommermonsun Mitteleuropas bezeichnen kann.

(Cold spells during winter months in northern Germany are caused by eastern and northeastern air currents with nocturnal radiation also playing a major role. Cold relapses during April, May, and June are the result of northern and northeastern air currents which are always accompanied by specific characteristic pressure distributions and are eventually caused by the different warming of land and water surfaces ... The cold relapse in June is not a short-duration event as assumed up to now, but merely the start of a more important natural phenomenon, extending over the months June, July, and August. Because of its causes and side-effects it may be called a summer monsoon.)

Thus, according to Almstedt's analysis based on meteorological observations between 1887 and 1906, cold relapses during winter periods in northern Germany are caused by easterly and north-easterly air movements. Relapses in April, May, and June are the result of northerly and north- westerly streaming of air masses. And the June relapse is not a short-term phenomenon, as previously assumed, but indicates the start of a prevalent natural phenomenon, which may be termed a European monsoon. Almstedt's thesis was extensively reviewed by Beno Gutenberg (1913) and later critically commented on by Koncek (1941). The so-called European monsoon is nowadays interpreted as an anomaly in the prevailing westerly winds.

In Göttingen Almstedt also met other young, later successful, and famous geophysicists and meteorologists, such as Ludger Mintrop (1880-1956), Beno Gutenberg (18891969), or Gustav Heinrich Angenheister (1878-1945), all members of the Wiechert school at the Institute of Geophysics in Göttingen.

\section{The period of the Great War}

The scientific and academic career of the young Almstedt was dramatically halted in 1914, when the First World War started. Almstedt was called up for military service. According to personnel notes in Almstedt's personnel files of the State Government of Lower Saxony, he served as a private in infantry regiment JR 92 at Berry-au-Bac in the Aisne department, participating in positional warfare between December 1914 and January 1915 (NLA WO, 2018). Later he was ordered to join airship battalion LB 1. Ludger Mintrop (1880- 


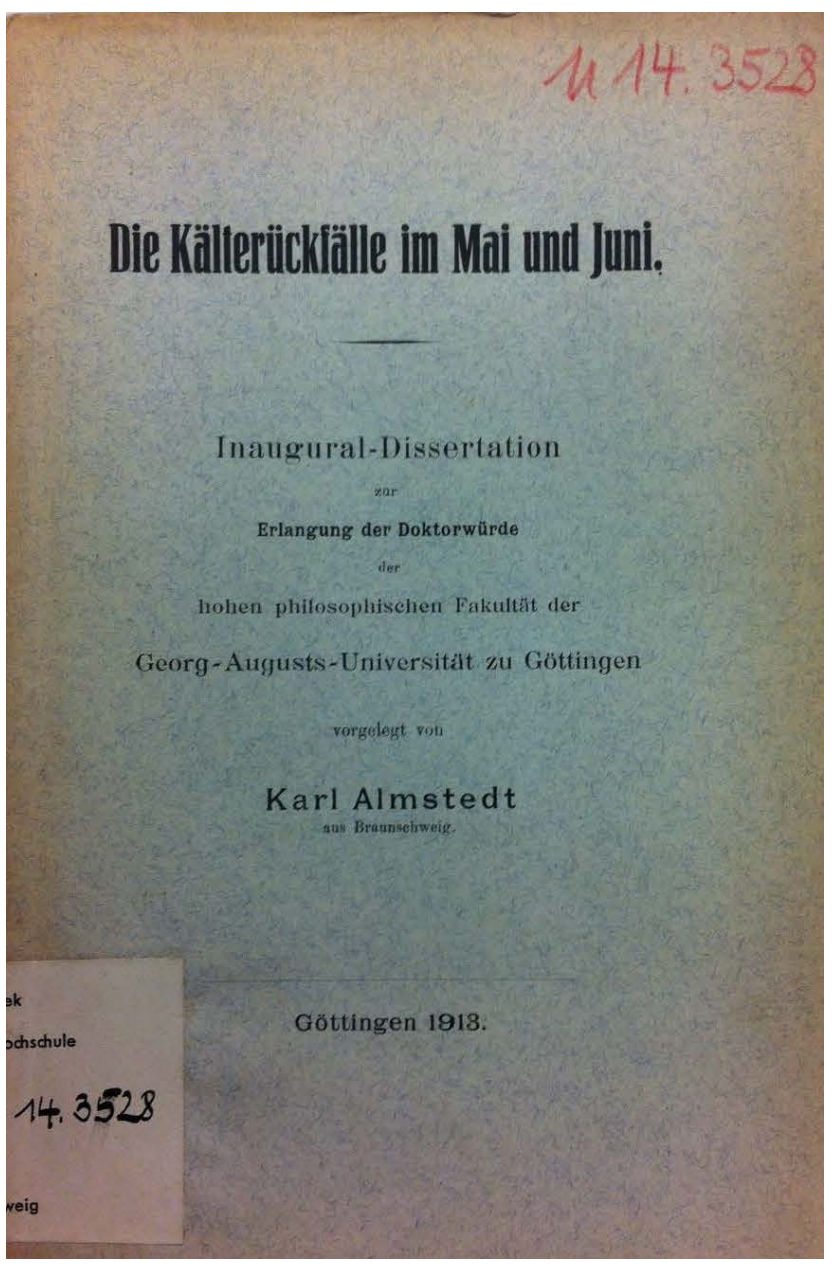

Figure 2. Title page of the dissertation of Karl Friedrich Almstedt, reproduced with the permission of the Universitätsbibliothek Braunschweig.

1956), whom he knew from his study time in Göttingen, held a license as an airship pilot and was also ordered to the western front to join an airship battalion (Lehmann, 1956). After the first battle of the Marne, battlefield reconnaissance became an important issue, with airships playing a major role. Almstedt was probably ordered to join the airship fleet because of his scientific meteorological knowledge. Most probably Mintrop pointed out his usefulness in joining the fleet's activities. In Almstedt's personal records (NLA WO, 2018), he reports on his reconnaissance services on 21/22 February 1916 with airship $L Z 95$ ( $L 48$; Fig. 3) flying in the region of Verdun, where the battle started on 21 February 1916, lasting for $303 \mathrm{~d}$ with about 1 million people killed (e.g. Brown, 1999). His handwritten curriculum vitae does not contain any further personal comments on these events.

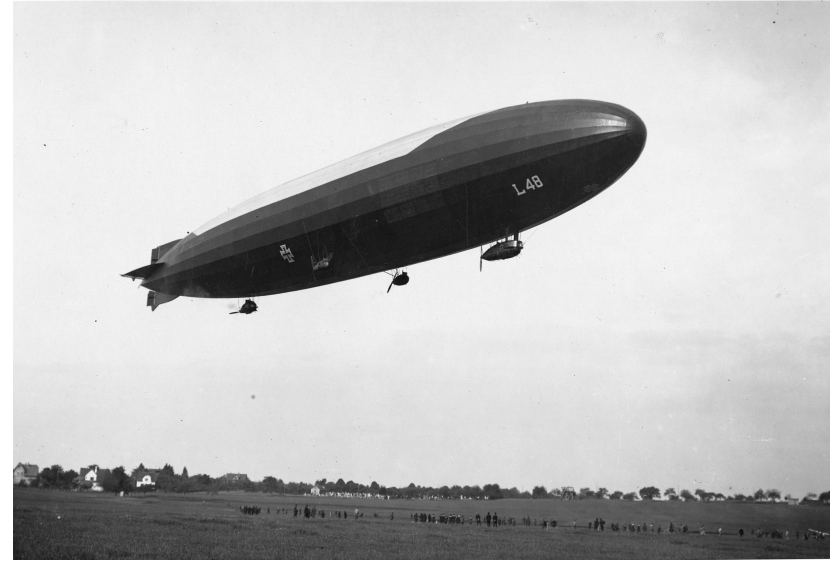

Figure 3. Airship LZ 95 (L48), the ship Almstedt flew with during the Verdun reconnaissance activities. (C) Archiv der Luftschiffbau Zeppelin $\mathrm{GmbH}$, with permission.

The next year, on 14 October 1917, Almstedt was made a reserve lieutenant. And on 27 January 1918, 10 months before the end of the First World War, he was ordered to join the Artillerie-Prüfungskommission (APK) in Berlin. The work of the APK, an artillery control commission founded in 1809, was the scientific and technical development, testing, and procurement of artillery material and ideas (e.g. Moewes, 1895). It was disbanded in 1918, after the end of the First World War.

The APK operated a test department where Rudolf Ladenburg (1882-1952) headed a special branch to study the possibilities of locating artillery pieces by optical, acoustic, seismic, and electro-magnetic means (Rechenberg, 1982). Ladenburg later moved to the Palmer Physical Observatory in Princeton, where he made further important contributions to atomic physics, nuclear physics, and astrophysics. Other highly talented physicists joined Ladenburg's team, such as Max Born (1882-1970) in the summer of 1915 (Einstein and Born, 1972), Alfred Landé (Schirrmacher, 2014), and Ernst von Angerer, known to Almstedt from his study days in $\mathrm{Mu}-$ nich. With von Angerer Rudolf Ladenburg published in 1921 a study on the propagation of sound in the atmosphere (von Angerer and Ladenburg, 1921). Their experiments reported on in this publication were conducted in Bavaria as well as Flanders in 1916 while members of the APK. The military aim of these experiments was source location of sound signals. Also, Leo Löwenstein (1879-1956), another young physicist in the service of the APK (Menges, 1987), presented to the artillery control commission Ein Verfahren zur Auffindung des Ortes von schallerzeugenden Gegenständen, a method to use sound measurement systems to locate artillery pieces. Löwenstein claimed a patent for his new technique in October 1913 and reported on its successful use in La Basseé near Lille (Löwenstein, 1928). 
Location of signals was also the topic of seismologists at that time. Another famous member of the APK was Ludger Mintrop (1880-1956), well known for his discovery of the Mintrop wave and founder of seismic refraction studies. Mintrop's wave is actually a boundary or head wave travelling along the boundary between two media with different wave-phase velocities and a quite general phenomenon (e.g. von Schmidt, 1938, 1939; Maecker, 1949). Mintrop also invented very efficient portable seismographs. And about his activities in the APK Keppner (1991, p. 22) reports the following.

He long tried in vain to convince the general staff that he was in a position with his portable seismographs to determine quickly and accurately the position of enemy gunfire. Only after the bloody Somme massacre was Mintrop able to convince Ludendorff's general staff of the possibilities of seismic locating. As a consequence, a demonstration of his method was made toward the end of 1916 at the Wahn artillery firing location. Mintrop located the enemy battery with such precision that Ludendorff approved 100 locating crews [...] However, qualified personnel and even suitable materials were scarce, and by the end of the war, the desired mass production of seismographs had never been attained.

Erich Ludendorff (1865-1937) was the leading German general in the First World War. The Wahn firing station was located near Cologne. A hundred locating crews certainly indicates a major wartime mobilization of German academics to test a new scientific tool at the front. The shortage of qualified personnel was certainly a motivation for Mintrop to initiate the relocation of Karl Almstedt from the western front to a much safer place in Berlin. The obviously existing network of members from the Wiechert school in Göttingen and beyond can be viewed as an invisible college (Crane, 1972), fostering seismic science for military purposes during the Great War. Being ordered to join the APK in Berlin obviously resulted in Almstedt becoming involved in a very lively scientific albeit military scientific environment. Whether he personally knew people like Max Born is not known. Mintrop's portable seismograph, the Mintrop apparatus, and its possibilities are also mentioned in a letter of Friedrich Kottler's (1886-1965) to Albert Einstein (1879-1955) dated 30 March 1918. In this letter, Kottler complains somewhat about having been ordered from the front to join the Technische Militär Komite in Vienna, the Austrian counterpart of the APK, and not being able to travel to Berlin to meet Einstein (Schulmann et al., 1998).

At the APK in Berlin Almstedt actively participated in furthering the seismic method. An example of Almstedt's measurements with the Mintrop apparatus is shown in Fig. 4 (Hort, 1922, p. 197). In the seismogram $B_{1}$ and $B_{2}$ denote the arrival of the longitudinal and transverse body waves, while $L$ indicates the arrival of the air wave. Almstedt obviously did a series of such experiments which allowed him to determine the longitudinal/transverse phase velocities at $3.13 / 1.76 \mathrm{~km} \mathrm{~s}^{-1}$. The Poisson number, the ratio of transverse strain to the applied axial strain, he determined to be $v=0.27$. Later Gutenberg (1929, p. 603) also referenced Almstedt's work. Nothing is known about the original publication or report on these measurements.

\section{Almstedt and the Weimar Republic}

In the course of the German demobilization Karl Almstedt was discharged from war service on 20 December 1918 and returned to Göttingen. There he became an assistant scientist at the Institute of Geophysics with Emil Wiechert until the end of March 1919. On 1 April 1919 he returned to Braunschweig and became a civil servant and candidate for the Lehramt an Höheren Schulen, an institution preparing young academics for a teacher's position at secondary schools. Almstedt passed, certainly without any problem, the scientific examination on 2 July 1919. He passed the pedagogical examination on 10 May 1920, thereby qualifying as a teacher at secondary schools in the state of Braunschweig (NLA WO, 2018). Starting on 1 April 1923 he became a secondary school teacher at the Reform-Real-Gymnasium in Braunschweig. This school was founded in 1828 as the Duchy's secondary school. During the Nazi period the school was renamed the Neue Oberschule, at the present time located in the neighbourhood of the Institut für Geophysik und extraterrestrische Physik of the Technische Universität Braunschweig. Almstedt worked as a teacher at the RealGymnasium until 31 March 1929, when he was promoted to new Headmaster of the Raabe-Schule, named after the famous writer Wilhelm Raabe (1831-1910). The Raabe-Schule was founded in 1861 as a private school and became a state school in 1922. It was not a full secondary school at that time. Almstedt's attempts to receive full recognition for his school as a secondary school were unsuccessful (e.g. Festschrift, 1961, p. 10).

The time after the Great War was a most interesting period for young, politically active teachers. During the imperial era under the German Emperor Wilhelm II (1859-1941), the civil rights of teachers were significantly reduced (e.g. Bölling, 1978, p. 24). This applied especially to members of the Sozialdemokratische Partei (SPD). In his imperial order of 1 May 1889 Wilhelm II wrote the following (quoted after Ritter and Kocka, 1982, p. 333).

Schon längere Zeit hat Mich der Gedanke beschäftigt, die Schule in ihren einzelnen Abstufungen nutzbar zu machen, um der Ausbreitung sozialistischer und kommunistischer Ideen entgegenzuwirken. 


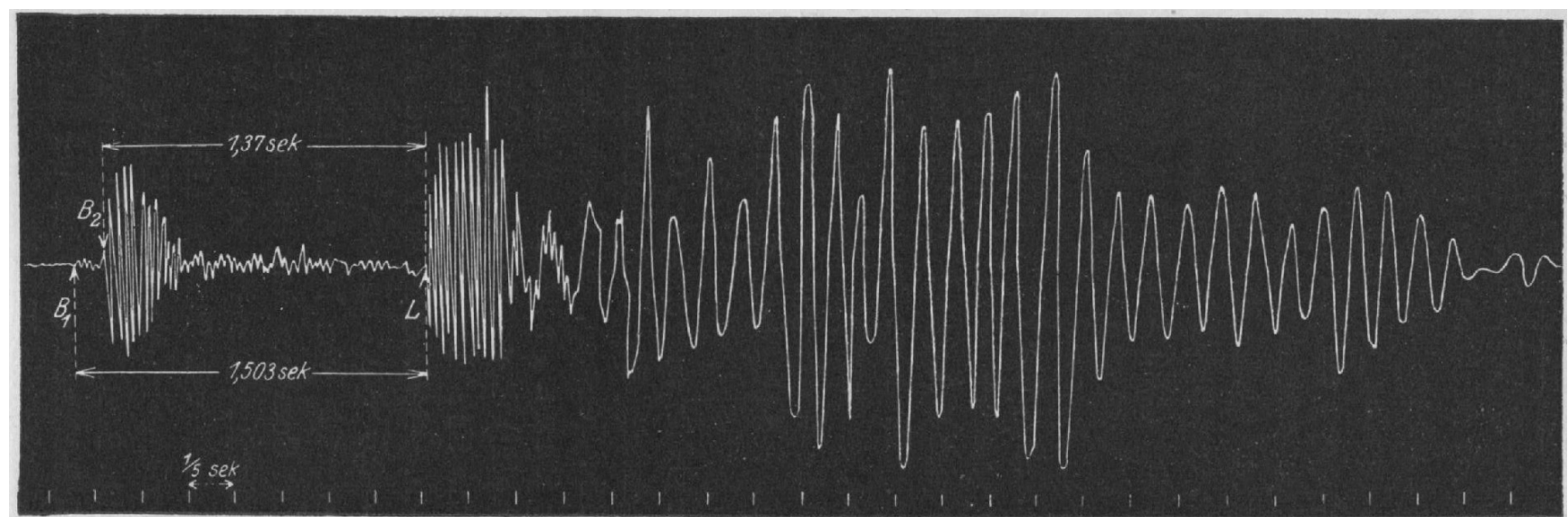

Figure 4. Seismic signal recorded by Karl Almstedt with Mintrop's portable seismometer at a distance of $900 \mathrm{~m}$ from a $13 \mathrm{~cm}$ artillery gun (reproduced from Hort, 1922, p. 198).

(For a long time I thought about the idea to use the school system to prevent the spread of socialistic and communistic ideas.)

The German Emperor explicitly stated in this order that schools on their different levels should be used as a means to counteract the diffusion of communistic and socialistic ideas. This order made it very difficult for teachers to be members of the SPD. This situation completely changed after the war. The Verfassung des Deutschen Reichs, the constitution of Weimar, was announced on 11 August 1919. This new constitution enabled a more liberal development of the German school system and boosted the Reformpädagogische Bewegung, the pedagogical reform movement in Germany (e.g. Scheibe, 2012).

Karl Almstedt obviously participated in these political and pedagogical activities. He was a member of the SPD as well as the Arbeitsgemeinschaft Sozialdemokratischer Lehrer (ASL), a working group of social democratic teachers. In which year he joined the SPD is not known. The corresponding documents were destroyed during World War II. Also, his personnel files of the State Government of Lower Saxony do not contain any information on this.

The ASL was founded in 1919 and aimed at coordinating the political, social, and cultural interests of the SPD in all pedagogical areas (e.g. Bölling, 1978, p. 120). Only members of the SPD could become members of the ASL. Almstedt was quite active in this working group. On 11 December 1926 he gave a talk entitled SPD und Höhere Schule (SPD and Secondary School) and on 26 November 1930 he lectured on Denkschulung als Aufgabe der Höheren Schule (Intellectual Training as a Task of the Secondary School). No manuscripts of these lectures exist anymore.

\section{The SEISMOS intermezzo and the foundation of the German Geophysical Society}

Almstedt's career as a teacher was interrupted between 1 May 1921 and 31 March 1922. During this time Karl Almstedt became the first employee of SEISMOS GmbH, an exploration company founded by Ludger Mintrop in Hanover on 4 April 1921. For several years SEISMOS was the only and leading seismic exploration company in the world. Based on Emil Wiechert's theoretical work, Mintrop's detection of the head wave, and his portable seismographs, already successfully tested during the war at the APK, Ludger Mintrop used the seismic method to search for hard coal, iron ore, and later also salt dome structures. The seismic method is based on the surface excitation of seismic waves and observation of reflected waves at the depth of geological structures with different seismic velocities there (for a more detailed and modern description of seismic and other methods of applied geophysics, see Telford et al., 2004).

In the very beginning SEISMOS GmbH had only six employees, but already in 1922 more than 20 people were working for Mintrop's prospering company (Geußenheimer, 1958). The first contracts were for the exploration of various regions in Germany. Two survey teams, each consisting of a scientist as the team leader, an evaluator, and a registrant, operated in 1922. Karl Almstedt was the leader of one of the teams, and the other was led by Mintrop himself. Almstedt's duties were also on theoretical bases. Mintrop reported the following (Mintrop, 1941, p. 49).

Meine ersten Mitarbeiter in der SEISMOS, insbesondere K. Almstedt ... haben vom Jahr 1921 an für den internen Gebrauch Formeln und graphische Darstellungen zur Ermittlung der Tiefen und Neigungen von zwei und mehreren untereinander liegenden Schichtgrenzen sowie für die Bestimmung der Wellengeschwindigkeiten in den einzel- 


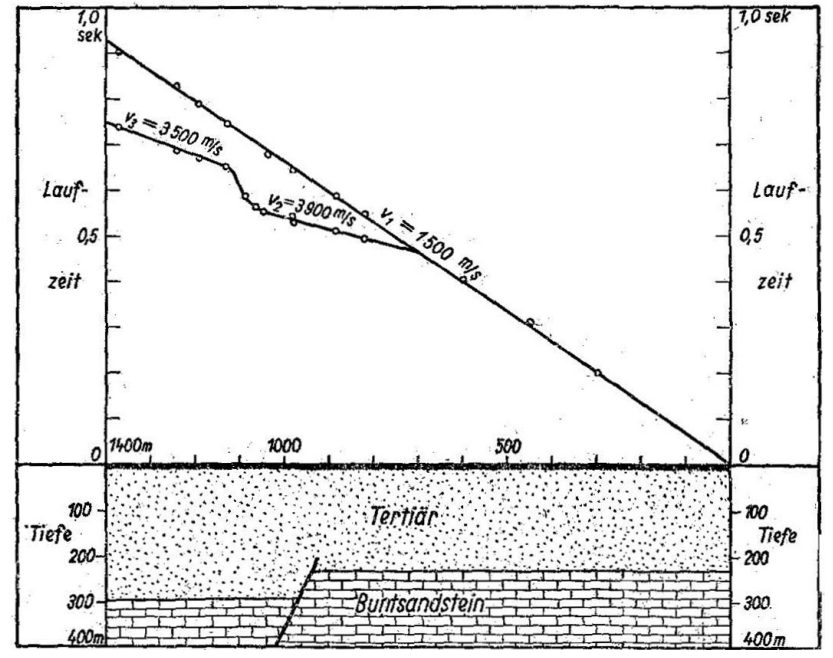

Figure 5. Travel time curves of the longitudinal waves, recorded above a geologically hidden fault zone. Below the tertiary surface a faulted region of red sandstone causes the two kinks in the travel time curve (from Mintrop, 1947).

nen Gebirgsschichten entwickelt und in zahlreichen, zum Teil recht schwierigen Fällen erprobt.

(My first collaborators at SEISMOS, especially, K. Almstedt ... developed from 1921, for internal use, formulas and graphical representations for the determination of the depth and tilt of two or more boundary layers lying one below the other as well as the determination of wave-phase velocities of each mountain strata. These were examined for many, partially very complex cases.)

His first collaborators, in particular Karl Almstedt, developed in 1921, for internal use, theoretical formulae as well as graphical displays to determine the depth and tilt of two or more geological layers lying among each other. Also, the seismic velocity needed to be determined, and the methods required intensive testing. Results were treated highly confidentially in view of a very competitive situation in the world's oil exploration sector. Employees of SEISMOS were carefully selected; many of them were related to Wiechert and his school in Göttingen. The invisible college was again active.

As an example of seismic measurements jointly made by Mintrop and Almstedt, Fig. 5 displays travel time curves of the longitudinal waves in regions where tertiary surface rocks hide a fault zone of red sandstone (Mintrop, 1947). As a source of this figure, Mintrop (1947) referenced Almstedt and Mintrop (1922), but in the list of references this study is not listed in further detail. A search for the original science document was unsuccessful.

For reasons which are not known, Karl Almstedt left the flourishing SEISMOS start-up in April 1922. Most probably this was related to the fact that he became engaged to a young lady from Hamburg, Frieda Herta Bubolz. They got married on 28 July 1923 in Hamburg. Maybe this new responsibility led Almstedt to decide against a somewhat insecure future in a young start-up company. The Almstedt couple never had children.

Though Almstedt left SEISMOS, he stayed in contact with his invisible college and became a founding member of the Deutsche Geophysikalische Gesellschaft (DGG - German Geophysical Society). The DGG was founded on 19 September 1922 in Leipzig as the Deutsche Seismologische Vereinigung and renamed the Deutsche Geophysikalische Gesellschaft in 1924. Its founding was initiated by Emil Wiechert and carried out during the hundredth annual meeting of the Gesellschaft deutscher Naturforscher und Ärzte (GdNÄ), an organization comparable to the American Association for the Advancement of Science. Differentiation of the various classical scientific disciplines marked the development of science in Germany in the late 19th and early 20th centuries (e.g. Szöllösi-Janze, 2002, p. 62). And the GdNÄ played a pivotal role in the specialization of natural science and medicine in Germany (e.g. Pfetsch, 1974, p. 307).

The 24 founding members were Karl Almstedt, Karl Andrée, Gustav Angenheister, Ernst-August Ansel, Rudolf Berger, Friedrich Burmeister, Friedrich Errulat, Immanuel Friedländer, Beno Gutenberg, Friedrich Haubold, Oskar Hecker, Franz Kossmat, Gerhard Krumbach, Wilhelm Löhr, Karl Mack, Ludger Mintrop, Peter Polis, Richard Schütt, Wilhelm Schweydar, August Sieberg, Ernst Tams, Julius Wagner, Emil Wiechert, and Conrad Zeissig. Almstedt was a member of the DGG until at least 1937 (Mitgliederverzeichnis, 1937). It is not known when he cancelled his membership. He is not listed as a member in the 1953 issue, the first issue of the Zeitschrift für Geophysik after the end of World War II.

\section{Almstedt's life under the Nazi regime}

Almstedt's promising career as a secondary school teacher was abruptly halted on 30 September 1933 by the so-called Gesetz zur Wiederherstellung des Berufsbeamtentums (Law for the Restoration of the Professional Civil Service) of the newly elected Nationalsozialistische Arbeiterpartei (NSDAP) under Adolf Hitler. This law, published on 7 April 1933, allowed the Nazis to remove Jewish people as well as all politically undesirable state officials from their positions. Karl Almstedt, a member of the SPD and the ASL, was immediately removed from his position as headmaster of the Raabe-Schule. As headmaster his annual income had been about 8000 Reichsmark; after his dismissal he received a reduced annual pension of about 3000 Reichsmark (NLA WO, 2018). His attempts to become a teacher at a private school in Braunschweig, the Sophien-Schule, a secondary school for girls, were unsuccessful. He was not allowed to pursue his profession. In the years following his dismissal he had 
a small additional income giving person-to-person lessons. His personal records do not indicate any renewed contacts in geophysics.

How to react in these difficult times? In November 1933 Karl Almstedt applied to become a member of the Sturmabteilung (SA). The SA was formed in 1920 and was the NSDAP paramilitary. Almstedt started as a candidate and was made a Sturmmann (storm trooper) of the SA reserve later (NLA WO, 2018). Members of the SA reserve were those older than 45 years. Almstedt left the SA in June 1935. According to his personal notes he became a member of the Nationalsozialistisches Fliegerkorps (NSFK), the Nazi air corps, in June 1936. This is obviously a mistake as the NSFK, a paramilitary organization in support of the Nazis, was founded by order of Adolf Hitler on 17 April 1937 (Kehrberg, 1942). The NSFK was a stepping stone for the resurrection of the German air forces. Almstedt was merely a supporting member, contributing a membership fee, but obviously not actively engaged in this Nazi organization. From 1 November 1940 he was also pushed to become a supporting member of the Nationalsozialistische Volkswohlfahrt (NSF), a Nazi charity organization. And on 1 February 1941 he joined the Nationalsozialistischer Lehrerbund (NSLB), the National Socialist teachers association. The NSLB was dissolved in 1943 by the NSDAP. Almstedt did not hold a post in either organization, NSF or NSLB.

To understand why a former active social democrat became a member of Nazi organizations, some further facts are of interest. From 1926 until his death in 1964 Almstedt lived in the same house in Braunschweig, Leonhardstraße 41. This house was known in Braunschweig as the Philologen-Haus, house of the philologists. In 1934 all its residents were teachers at various schools in Braunschweig. The ground floor was used by the Waisen- und Hilfskasse des Braunschweigischen Philologenvereins, an aid and support office of the local philologist society for orphans and others (Braunschweigisches Adressbuch, 1934, p. 143). The most prominent resident of Leonhardstraße 41 was Wilhelm Hesse (1901-1968), Lord Major of Braunschweig from 1933 until 1945 (e.g. Ehrhard, 2013). Wilhelm Hesse studied physics and mathematics in Braunschweig and Göttingen, receiving a PhD from the University of Göttingen in 1926. In 1930 he became a member of the NSDAP, whose Braunschweig district leader he was from 1932 until 1938. With Wilhelm Hesse in the same apartment block, Karl Almstedt had a most efficient Blockwart living next door to him. A Blockwart, or block warden, was (Evans, 2007, p. 69)

a popular name given to low-level officials of the Nazi Party, each of whom was responsible for a block of apartments or houses, where he had to ensure that people took proper air-raid precautions, hung out flags on Hitler's birthday and similar occasions, and refrained from engaging in illegal or subversive activities. The Block Wardens kept a close watch on former Communists and Social Democrats, listened out for expressions of dissatisfaction with the regime, and could punish political or social deviance by a variety of means ranging from stopping the offenders' welfare benefits to reporting their names to the district Party organisation for forwarding to the Gestapo.

Living in such proximity to a super block warden was certainly not easy. The Nazis had set up a very effective system of coercion and control. This induced Almstedt to join the above-mentioned organizations. In a questionnaire of the Military Government of Germany dated 1 May 1945, Almstedt stated in English the following (NLA WO, 2018).

It appears rather strange, when the headmaster of a secondary school loses his position on 1. X. 1933 by the Nazis and tries to join the S$\mathrm{A}$ in the next month. These were the motives: As a higher official and political adversary I was constantly watched by the Gestapo as well as by the 'staircase-snufflers', who collected contributions and information for the Nazis from the surveyed persons and their neighbours. Moreover, the Kreisleiter and Mayor of the town lived in the same house with me at that time. The least incautiousness might have had the worst consequences for me. Therefore, I tried to lull my surveyors by joining the S-A. In 1935 I succeeded in getting free again from SA by joining a new formed 'AntiAircraft Sturm' in the 'Luftsportverband'. When this paramilitary organisation came under the command of the Reichswehr in 1936 (January), I was dismissed, because I had been declared as 'national unreliable', since I had been a member of the SPD (Social Democratic Party); the Reichswehr declined officers, on whom political punishment had been inflicted. I was assigned to the civilian side of the Luftsportverband and sometime later to the NSFK. In 1933-39 I refused several times to become a member of the NSV as long as I was forbidden to work in profession even as a privateschool. During the war - in 1940 - I was summoned as an assistant teacher and then I had to join the NSV and the NSLB, both controlled by ministry.

Almstedt was also in close contact with Kuno Rieke (1897-1945), Speaker of the Parliament of Braunschweig from 1930 until 1933, imprisoned in 1935 in Dachau concentration camp, where he died in 1945. Almstedt reports an occasion when Rieke's wife came to his apartment late one evening, asking to hide her son as she was afraid about further attacks by the SA on the apartment of the Rieke family. Kuno Rieke was a teacher like Almstedt and a leading figure of the SPD in the region of Braunschweig. Other 


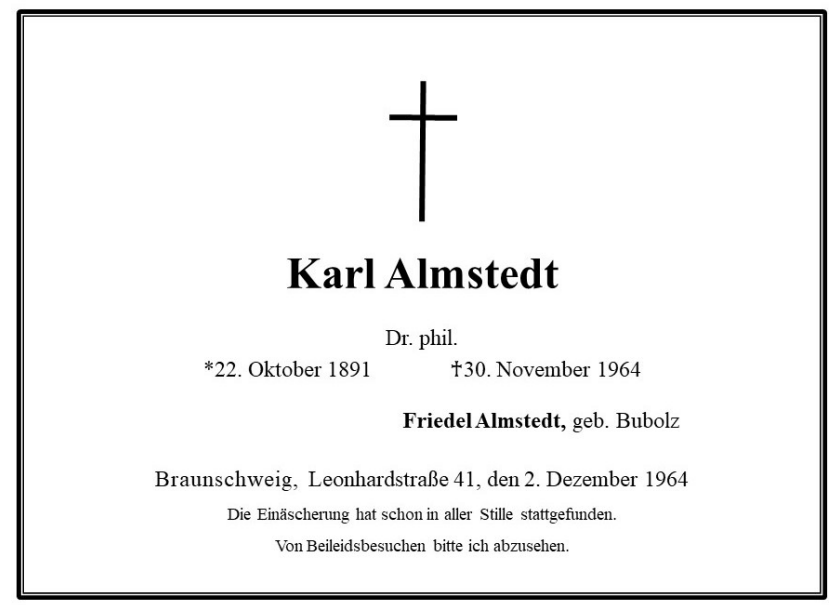

Figure 6. Death notice by Friedel Almstedt. The detailed information reads as follows. The cremation has already taken place in private. I ask you to refrain from visits of condolence. Reproduced from the Braunschweiger Zeitung. No. 282, 3 December 1964.

well-known comrades from the Braunschweig region were Heinrich Jasper (1875-1945), between 1919 and 1930 several times Prime Minister of the Free State of Braunschweig (Eckert, 1978), and Otto Grotewohl (1894-1964), later Prime Minister of the Deutsche Demokratische Republik (DDR) from 1949 until 1964. Almstedt was certainly personally known to both of them.

Increasing difficulties due to the severe wartime situation led the authorities in Braunschweig to order Almstedt back to the Raabe-Schule. From 30 August 1940 until 31 August 1944 he worked as an assistant teacher in Braunschweig. From 1 September 1944 until the end of the war he was assigned to the secondary school for boys in Seesen, a small town south of Braunschweig, in the western part of the Harz mountains. This time he was promoted to the level of Studiendirektor, deputy headmaster.

\section{Post Second World War life and career}

At the end of World War II, because of his position as Studiendirektor, Karl Almstedt was suspended from his position on 24 May 1945 by the Military Government of Germany. The suspension was lifted on 30 May 1945. Already on 28 May 1945 he was appointed as a Hilfsreferent beim Braunschweigischen Staatsminsterium, assistant consultant to the new government of the State of Braunschweig. And on 21 July 1945 Almstedt returned to his 1933 position as headmaster of the Raabe-Schule. On 27 July 1946 he was appointed as Oberstudiendirektor and headmaster of the Martino-Katharineum, the oldest secondary school in Braunschweig, founded in 1415 . He was not immediately active in this new position, but continued to be responsible for the reconstruction and modernization of the secondary school sys- tem in the Braunschweig region. Until 1 May 1950 he served as Referent für das Höhere Schulwesen, consultant to the President of the Administrative District of Braunschweig of the newly formed federal state of Lower Saxony. For health reasons he asked to be released from this important position, and he returned to the Martino-Katharineum, continuing his profession as a teacher after a hiatus of 17 years.

Until his retirement in 1957 Almstedt played the major role in rebuilding the Martino-Katharineum, its school house having been destroyed during the Royal Air Force raid on 15 October 1944 (Bödecker, 1965, p. 70), as well as the teaching faculty and daily school education. The Festschrift published in 1965 to commemorate the 550th anniversary of the school describes Almstedt as a "rastlos arbeitenden Schulmann" with "nie erlahmender Arbeitskraft" (an indefatigable teacher of unflagging energy) (Bödecker, 1965, p. 78). With all his energy and administrative ingenuity, he managed to get the new school building finished in October 1953. Only his wish for an astronomical observatory on the roof of the new school building was not fulfilled.

He was a highly respected teacher. His former pupil Eckhard Schimpf (personal communication, 2019) remembers the following.

As a teacher he spoke softly, not accepting any little naughtiness. He was a most respected authority; in his classroom it was always quiet. And, as far as I remember, he never used a schoolbook. He taught from memory, having absolutely mastered his subject.

Furthermore, he was able to motivate young boys from his school to join in on Saturdays to clean bricks, collected in the ruins of Braunschweig, from mortar and sort them for the new school building (Schimpf, 2016). New bricks were a scarce commodity in post-war Germany. Eckhard Schimpf remembers an episode in the mid-fifties. Bullet pencils were about to become very fashionable in Germany. Almstedt as headmaster of the Martino-Katharineum prohibited the use of Kulis (as they are still called in Germany today), arguing that this modern tool would ruin one's handwriting. Only fountain pencils were allowed for home and class work (Schimpf, 2016).

After retiring as headmaster of the Martino-Katharineum in 1957, Almstedt became an "assistant" teacher at the Ricarda-Huch-Schule, at that time a secondary school for girls in Braunschweig. The school building was located close to his long-time home at Leonhardstraße 41. On the morning of 30 November 1964, on the way to his school, he was involved in a car accident and fatally injured. He was cremated and his ashes buried in the cemetery of Braunschweig (Fig. 6). More detailed obituaries from his former colleagues at the Martino-Katharineum and Ricarda-Huch-Schule, also published in the Braunschweiger Zeitung, commemorate the life and achievements of this fine member of the group of founders of the Deutsche Geophysikalische Gesellschaft. 
Data availability. The bibliographic and other material used in this study is available from various state and university libraries, the Niedersächsisches Landesarchiv, Abteilung Wolfenbüttel, and other archives accessible via the World Wide Web. Where available digital object identifiers are given; otherwise, URLs are provided. Some information is also based on personal comments from people who remember Karl Almstedt.

Competing interests. The author declares that there is no conflict of interest.

Acknowledgements. This study was motivated by Franz Jacobs, who initiated my interest with his question "Who was Karl Almstedt? We only know he is from Braunschweig!" Asking the right question is often the starting point for a joyful journey. Thanks Franz Jacobs. Much of the material used for this biographical sketch is from the personal records of Karl Almstedt, archived in the Niedersächsisches Landesarchiv in Wolfenbüttel. My sincere thanks go to this fine institution for important support. The library of the Technische Universität Braunschweig was another treasure trove. Sincere thanks to my university library. I also owe the Archive of the Ludwig-Maximilians-Universität in Munich for making available information about Almstedt's study period there. Many thanks also to Friederike Borß, Inge Kossebau, and Christine Rogge from the alumni society of the Ricarda-Huch-Schule in Braunschweig as well as Eckhard Schimpf, former deputy editor-inchief of the Braunschweiger Zeitung. They remember Karl Almstedt as a teacher. Support from the Archive of the Luftschiffbau Zeppelin $\mathrm{GmbH}$ in Friedrichshafen is gratefully acknowledged. Thanks also to Hans-Jürgen Wolff, Stadtallendorf, for his extensive information on the Artillerie Prüfungskommission. Most interesting were the many discussions about Reformpädagogik with my wife Gisela Sieverdingbeck-Glaßmeier.

Review statement. This paper was edited by Kristian Schlegel and reviewed by Alexander Rudloff and Johannes Schweitzer.

\section{References}

Almstedt, K. F.: Die Kälterückfälle im Mai und Juni, Dissertation, University of Göttingen, 1913.

Bödecker, J. D. (Ed.): Festschrift zur 550-Jahr-Feier Gymnasium Martino-Katharineum, Braunschweig, 1965.

Bölling, R.: Volksschullehrer und Politik, Vandenhoeck\&Ruprecht, Göttingen, 1978.

Braunschweigisches Adreßbuch für das Jahr 1934: Meyer, Braunschweig, 1934.

Brown, M.: Verdun 1916, Tempus, Stroud, 1999.

Crane, D.: Invisible Colleges: Diffusion of Knowledge in Scientific Communities, University of Chicago Press, Chicago, 1972.

Eckert, G.: Jasper, Heinrich. Neue deutsche Biographie, Bayerische Staatsbibliothek, München, p. 361, 1978.

Einstein, A. and Born, M.: Briefwechsel 1916-1955, p. 14, Rowohlt Taschenbuchverlag, Reinbek bei Hamburg, 1972.
Evans, R. J.: Coercion and consent in Nazi Germany, Proc. Brit. Acad., 151, 53-81, 2007.

Ehrhardt, F.: Dr. Wilhelm Hesse (1933-1945), in: Die Braunschweiger Bürgermeister. Von der Entstehung des Amtes im späten Mittelalter bis ins 20. Jahrhundert, edited by: Steinführer, H. and Böhler, C., Appelhans Verlag, Braunschweig, 2013.

Festschrift zur 100-Jahrfeier der Raabeschule in Braunschweig, Braunschweig, 1961.

Geußenheimer, O.: Das Goldene Buch der Angewandten Geophysik, Vol. 1: Geschichte der Angewandten Seismik, Teil I: Die Geschichte der SEISMOS, unpublished manuscript, Hannover, 1958.

Gutenberg, B.: Besprechung Karl Almstedt, Die Kälterückfälle im Mai und Juni, Gerlands Beiträge zur Geophysik, 13, 212-216, 1913.

Gutenberg, B. (Ed.): Lehrbuch der Geophysik, Gebrüder Bornträger, Berlin, 1929.

Hort, W.: Technische Schwingungslehre, Berlin, 1922.

Kehrberg, A.: Das Nationalsozialistische Fliegerkorps - Die Vorschule der deutschen Flieger, Schuhmacher, Berlin, 1942.

Keppner, G.: Ludger Mintrop, The Leading Edge of Exploration, 10, 21-28, https://doi.org/10.1190/1.1436838, 1991.

Koncek, N.: Synoptische Betrachtungen der Störungen im Jahresgang der meteorologischen Elemente im Laufe des Sommerhalbjahres in Mitteleuropa, Meteorol. Z., 58, 79-88, 1941.

Lehmann, K.: Ludger Mintrop. Der große Markscheider und Geophysiker, Prakla-Seismos Report, Essen, 1956.

Löwenstein, L.: Die Erfindung der Schallmessung, Die Schalltechnik, 2, 21-24, 1928.

Ludwig-Maximilians-Universität München: Personalstand der Ludwig-Maximilians-Universität München, available at: http://nbn-resolving.de/urn/resolver.pl?urn=nbn:de:bvb: 19-epub-9669-3 (last access: 13 April 2020), 1910.

Ludwig-Maximilians-Universität München: Personalstand der Ludwig-Maximilians-Universität München, available at: http://nbn-resolving.de/urn/resolver.pl?urn=nbn:de:bvb: 19-epub-9670-4 (last access: 13 April 2020), 1911.

Maecker, H.: Quantitativer Nachweis von Grenzschichtwellen in der Optik, Ann. Phys., 4, 409-431, 1949.

Menges, F.: Löwenstein, Leo, in: Neue Deutsche Biographie 15, pp. 106 (online version), available at: https: //www.deutsche-biographie.de/pnd126461422.html\#ndbcontent (last access: 13 April 2020), 1987.

Mintrop, L.: Geophysikalische Verfahren zur Erforschung von Gebirgsschichten und Lagerstätten, in: Die technische Entwickelung des deutschen Steinkohlenbergbaues seit der Jahrhundertwende, edited by: Verein für bergbauliche Interessen, Verlag Glückauf, Essen, 1941.

Mintrop, L.: 100 Jahre physikalische Erdbebenforschung und Sprengseismik, Die Naturwissenschaften, 10, 289-295, 1947.

Mitgliederverzeichnis der Deutschen Geophysikalischen Gesellschaft, Zeitschrift für Geophysik, 13, 201, 1937.

Moewes, K.: Kurzgefaßte Geschichte der Königlich Preußischen Artillerie-Prüfungs-Kommission, Moewes, Berlin, 1895.

Niedersächsisches Landesarchiv Wolfenbüttel, NLA WO 4 Nds Zg. 63/1992 Nr. 3, 2018.

Pfetsch, F.: Zur Entwicklung der Wissenschaftspolitik in Deutschland, Duncker \& Humblot, Berlin, 1974. 
Rechenberg, Helmut: Ladenburg, Rudolf, in: Neue Deutsche Biographie, 13, pp. 391 (online version), available at: https://www. deutsche-biographie.de/pnd1 16643803.html\#ndbconten (last access: 13 April 2020), 1982.

Ritter, G. A. and Kocka, J. (Eds.): Deutsche Sozialgeschichte 18701914, C. H. Beck, München, 1982.

Scheibe, W.: Die Reformpädagogische Bewegung, Beltz, Basel, 2012.

Schimpf, E.: Von der Liebe zu Füllern und Drehbleistiften, Braunschweiger Zeitung, 24 June 2016.

Schirrmacher, A.: Die Physik im Großen Krieg, Phys. J., 13, 43-48, 2014.

Schulmann, R., Kox, A. J., Janssen, M., and Illy, J. (Eds.): The collected papers of Albert Einstein, Vol. 8, Part B: The Berlin years: Correspondence 1914-1918, p. 707, Princeton University Press, Princeton, 1998.
Szöllösi-Janze, M.: Die institutionelle Umgestaltung der Wissenschaftslandschaft im Übergang vom späten Kaiserreich zur Weimarer Republik, edited by: vom Bruch, R. and Kaderas, B., Wissenschaften und Wissenschaftspolitik, Stuttgart, 2002.

Telford, W. M., Geldart, L. P., and Sheriff, R. E.: Applied Geophysics, Cambridge University Press, Cambridge, 2004.

von Angerer, E. and Ladenburg, R.: Experimentelle Beiträge zur Ausbreitung des Schalls in der freien Atmosphäre, Ann. Phys., 371, 293-322, 1921.

von Schmidt, O.: Über Knallwellenausbreitung in Flüssigkeiten und festen Körpern, Zeitschr. f. technische Physik, 12, 554-561, 1938.

von Schmidt, O.: Über Kopfwellen in der Seismik, Zeitschr. f. Geophys., 15, 141-148, 1939. 